\title{
CIEMNOŚĆ WIARY WSPÓŁCZESNEGO ŚWIATA. PRÓBA ODPOWIEDZI WIERZĄCEGO NA PODSTAWIE KSIĘGI HIOBA, PSALMU 22 ORAZ DOŚWIADCZENIA ŚW. TERESY Z LISIEUX
}

\section{i. Czas milczenia Boga}

Filozofowie i myśliciele nowożytności, szczególnie wieku XIX aż po XXI, wydali wyrok na Boga. Ogłosili, że zamilkł, a nawet, że umarł. Przyczyniły się do tego okrutne wydarzenia: wojny, rewolucje, gułagi i obozy koncentracyjne. Wielkie cierpienie przesłoniło ciemnymi chmurami zwątpienia jasność nieba wiary. Bóg zasiadł na ławie oskarżonych jako główny winowajca tych okrucieństw. Sędziowie wciąż zadają Mu pytanie, dlaczego na to wszystko przyzwolił. A On milczy. Tak przynajmniej oni rozumieją Jego reakcje. Niektórzy skazują Go na nieistnienie. Nie było bowiem Boga w Oświęcimiu czy na Łubiance, twierdzą, więc najlepiej uznać, że Go po prostu nie ma.

W przejmujący sposób o kryzysie wiary w Boga mówią również współczesna literatura i sztuka, a także teologia duchowości. Jeden z najwybitniejszych dramaturgów w dziejach ludzkiej historii, Samuel Beckett, ustami bohatera sztuki Czekając na Godota wypowiada porażającą diagnozę śmierci Boga:

Bóg osobowy qua - qua - qua - qua - qua z siwą brodą qua - qua istnieje poza przestrzenią i czasem i dopiero z wyżyn swojej boskiej apatii (...) swojej boskiej afazji pała do nas miłością z paroma wyjątkami... ${ }^{1}$

1 S. BeCKetr, Czekając na Godota, w: tenże, Utwory wybrane, Warszawa 2017, s. 47. 
Beckett jest bezlitosny wobec Boga dalekiego, niemego i pełnego niemocy. Taki obraz boskiej istoty ukształtował sobie tuż po II wojnie światowej. Wtedy to właśnie został opublikowany jego najsłynniejszy utwór dramatyczny.

W Polsce wyrazicielem duchowego kryzysu w czasach powojennych był Tadeusz Różewicz, także dramatopisarz, ale przede wszystkim poeta. W równie porażającym wyznaniu u progu drogi twórczej mówi:

\author{
Okaleczony nie widziałem \\ ani nieba ani róży \\ ptaka gniazda drzewa \\ świętego Franciszka \\ Achillesa i Hektora \\ Przez sześć lat \\ buchał w nozdrza opar krwi \\ Nie wierzę w przemianę wody $w$ wino \\ nie wierzę w grzechów odpuszczenie \\ nie wierzę w ciała zmartwychwstanie².
}

Wyznanie młodego poety uderza szczerością i jest swoistym manifestem powojennego pokolenia, które wkracza w życie z doświadczeniem koszmaru, jaki ludzkości zgotowały dwa totalitaryzmy - faszystowski i bolszewicki. Jednak można też na sytuację duchową ludzkości w epoce powojennej spojrzeć oczami teologa duchowości. Czynią tak Jan Paweł II w Liście apostolskim Magister in fide i nieżyjący już karmelita o. Wilfrid Stinissen w publikacji pod tytułem Noc jest mi świattem:

Doktor Mistyczny przyciąa dzisiaj szczególną uwagę wielu wierzących i niewierzących swym opisem nocy ciemnej jako doświadczeniem typowo ludzkim i chrześcijańskim. Nasza epoka przeżyła dramatyczne momenty, w których doświadczyła boleśnie uczucia milczenia czy nieobecności Boga: doświadczenie klęsk i nieszczęść, jak wojny albo jak pochłaniający wiele niewinnych istot holokaust. To wszystko pozwala na glębokie zrozumienie znaczenia symbolu nocy, nadając mu charakter znaczenia zbiorowego, zastosowanego do rzeczywistości samego życia, nie tylko do pewnego etapu życia duchowego ${ }^{3}$.

T. RóżEWICz, Lament, w: tenże, Wybór poezji, Wrocław 2019, s. 9.

JaN PAwez II, List apostolski Magister in fide z okazji 400-lecia śmierci św. Jana od Krzyża, http:// www.zyciezakonne.pl/dokumenty/kosciol/jan-pawel-ii/jan-pawel-ii-listy-i-przeslania/199012-14-watykan-list-apostolski-magister-in-fide-z-okazji-czterechsetlecia-smierci-sw-jana-odkrzyza-22434/(dostęp: 12 listopada 2019). 
Jan Paweł II nie waha się przyrównać noc ciemną Jana od Krzyża do ciemności, które znamionują naszą współczesność. Można by mówić o kolektywnej nocy ciemnej, która dotyczy całej ludzkości. Bóg nie jest już oczywistą rzeczywistością rozwiązującą wszystkie problemy i odpowiadającą na wszystkie pytania. Nie uczestniczy już w życiu publicznym. Być chrześcijaninem to nie jest już coś oczywistego, społeczeństwa coraz mniej opierają się na chrześcijańskich zasadach. (...) Ewangelia nie jest już normą etyczną, a gdzież szukać takich, którzy widzieliby w Kościele Mater et magistra (Matkę i nauczycielkę)? ${ }^{4}$

Nad światem, zdaniem szwedzkiego teologa duchowości, rozciąga się globalna noc ciemna. Odpływ zabiera ze sobą wszystko, co było niegdyś stabilnym gruntem, na którym wspierała się święta budowla wiary. Lecz odpływ to także coś, co zapowiada przypływ. Powrót dnia rozświetlającego mroki współczesności.

\section{BIBLIJNE TEKSTY O NOCY WIARY}

Sięgnijmy do kilku biblijnych świadectw opisujących zmaganie się z milczeniem Boga. Naszą uwagę skierujemy najpierw na postać Hioba, następnie wczytamy się w początkowy werset Psalmu 22, będący słowami modlitwy Jezusa na krzyżu.

\subsection{Księga Hioba - zapis udręki człowieka i chwały Boga}

Hiob jest tajemniczym mieszkańcem starożytnego Wschodu. Nie jest Hebrajczykiem, ale wierzy w jedynego Boga i Jemu składa ofiary. Jego życie jest świątobliwe i szczęśliwe, ma liczną rodzinę i wielkie bogactwa. W pewnym momencie traci wszystko. Dzieją się w jego życiu takie rzeczy, jakby Bóg karał go za grzechy. Tymczasem on wie, że nie popełnił wielkich nieprawości i cierpi bez żadnej zrozumiałej przyczyny. Skarży się, obwiniając Boga w słowach, można by powiedzié, zuchwałych:

Na jedno więc, rzekłem, wychodzi, prawego ze złym razem zniszczy.

Gdy nagła powódź zabija,

drwi z cierpień niewinnego,

ziemię dał w ręce grzeszników,

sędziom zakrywa oblicza.

Jeśli nie On - to kto właściwie? (Hi 9, 22-24).

4 W. Stinissen, Noc jest mi świattem, Kraków 1993, s. 91. 
Jednak takie stwierdzenie nie satysfakcjonuje go i pragnie usłyszeć odpowiedź od samego Boga, ku Niemu więc kieruje wszystkie swoje pytania i wątpliwości:

Życie obrzydło mojej duszy, przedstawię Jemu swą sprawę, odezwę się w bólu mej duszy!

Nie potępiaj mnie, powiem do Boga.

Dlaczego dokuczasz mi, powiedz!

Przyjemnie Ci mnie uciskać, odrzucać dzieło swoich rąk i sprzyjać radzie występnych? (Hi 10, 1-3).

Bóg jest więc dla Hioba ostateczną i jedyną instancją mogącą odpowiedzieć mu na pytanie o sens zła i cierpienia w jego życiu i w egzystencji wszystkich bytów.

Jan Paweł II, snując refleksję o sensie ludzkiego cierpienia, pisze na ten temat w liście apostolskim Salvifici doloris:

Tylko człowiek (...) cierpiąc wie, że cierpi i pyta: dlaczego? (...) Jest to pytanie trudne, podobnie jak (...) inne, bardzo pokrewne tamtemu, pytanie o zło. (...) Jedno i drugie pytanie jest trudne, gdy stawia je człowiek człowiekowi, ludzie ludziom - a także, gdy stawia je człowiek Bogu. Człowiek bowiem nie stawia tego pytania światu, jakkolwiek cierpienie wielokrotnie przychodzi do niego od strony świata, ale stawia je Bogu jako Stwórcy i Panu świata. I jest rzeczą dobrze znaną, że na gruncie tego pytania dochodzi nie tylko do wielorakich załamań i konfliktów w stosunkach człowieka z Bogiem, ale bywa i tak, że dochodzi do samej negacji Boga. Jeśli bowiem istnienie świata otwiera jakby wzrok duszy ludzkiej na istnienie Boga, na Jego mądrość, wszechmoc i wspaniałość, to zło i cierpienie zdają się zaćmiewać ten obraz-czasem w sposób radykalny, zwłaszcza wobec codziennego dramatu tylu niezawinionych cierpień, a także tych win, które uchodzą bezkarnie. Ta przeto okoliczność - może bardziej niż jakakolwiek inna - wskazuje, jak doniosłe jest pytanie o sens cierpienia. (...) Pytanie to człowiek może postawić Bogu $z$ sercem rozdartym, gdy umysł jest pełen przygnębienia i niepokoju; Bóg zaś, jak to widzimy już w objawieniu Starego Testamentu, słucha tego pytania i oczekuje na nie. Znalazło to swój najżywszy wyraz w „Księdze Hioba”.

W tekście owej księgi nie ma choćby cienia wątpliwości w istnienie Boga. To przekonanie o Jego bezspornej egzystencji pokrywa się z całą biblijną tradycją głębokiej

5 Jan Pawee II, Salvifici doloris - O chrześcijanskim sensie ludzkiego cierpienia, Rzym 1984, nr 9-10. 
pewności, iż Jahwe JEST. Potwierdzeniem tego są słowa Elihu: „Wszechmocny jest któż Go dosięże? Pełen potęgi, świętości, bogaty w pewność, nie w ucisk" (Hi 37, 23).

Paradoksalnie można nawet stwierdzić, iż doświadczenie cierpienia, które w myśl słów Hioba budzi w człowieku pragnienie nicości jako ukojenia egzystencjalnego bólu, jest jednocześnie wielkim wołaniem do Tego, który Jest „podstawą wszechrzeczy”, gwarantujacca wszystkim poczucie sensu i ładu, egzystencjalnej harmonii, by objawił się w całej pełni swojego Bytu.

Odwróć Twój wzrok, niech trochę rozjaśnię oblicze, nim pójdę, by nigdy nie wrócić, do kraju pełnego ciemności, do ziemi czarnej jak noc, do cienia chaosu i śmierci, gdzie świeca jedynie mroki (Hi 10, 20b-22).

W powyższych słowach Hiob wyraża dramat milczącej i potępiającej obecności Boga. Mówi: „pozwól mi choćby ślinę przełknące”. By to zrobić, trzeba mieć choć chwilę odpoczynku, oddechu, a Hiob jest do tego stopnia pod wrażeniem prześladującego go Bożego Oblicza, iż nie jest w stanie wykonać tak elementarnej czynności fizjologicznej.

To, co sprawia, że Hiob cierpi, jest dokładnie tym samym, co powoduje odczucie bycia obserwowanym we własnym domu przez wścibskiego sąsiada. Można stwierdzić, iż człowiek mający świadomość nieustannie skierowanego ku niemu spojrzenia Bożego nigdy tak naprawdę nie czuje się dobrze w swoim domu, gdyż wciąż przeszkadza mu przeświadczenie o cudzej, niepożądanej obecności. Zmuszony jest więc do bycia aktorem, do odgrywania roli, która zostałaby zaakceptowana przez obserwatora. Tym samym człowiek ten nigdy tak naprawdę nie może być sobą, nie może siebie do końca wyrazić. Jest jak gdyby unicestwiony przez to badające, „wścibskie” spojrzenie Boga, które go ogranicza, odbiera mu możliwość bycia sobą. To obce spojrzenie wymaga od niego rachunku, ono go bada i sądzi.

We współczesnej, dwudziestowiecznej myśli egzystencjalnej temat ten wysunął się na pierwszy plan. Dla Sartre'a bowiem relacja z Bogiem polega na bolesnym fakcie bycia obserwowanym, na uświadomieniu sobie, że jest się nieustannie wobec wzroku Innego. Możemy być zaskoczeni, że teoretyk egzystencjalizmu tak wiele zaczerpnął z przesłania Księgi Hioba. Jednak nie poszedł on do końca w swych intelektualnych poszukiwaniach tropem męża z Us. Zatrzymał się niejako w połowie drogi. Nazywając - tak jak Hiob - Boga swoim wrogiem, zastosował wobec tegoż wroga manewr obronny, polegający na wyeliminowaniu Go z pola walki. $W$ imię absolutnej niezależności człowieka, jego prawa do bycia w pełni wolną istotą Sartre zanegowat istnienie Boga. Pisał o tym między innymi w dramacie Diabet $i$ Bóg: 
Od chwili, kiedy Boga nie ma, nie jesteś złudzeniem, bo gdyby Bóg był, bylibyśmy tak od niego zależni, że nie mielibyśmy swej własnej egzystencji. Bylibyśmy tylko cieniami i zjawiskamí.

André Louf w książce Żyć łaska, analizując cierpienie Hioba, dostrzega w jego postawie zbieżność z tym, co przeżywał Sartre:

Wszystkie jego wysiłki prowadzą go - choć sam nie zdaje sobie z tego sprawy - do tego samego dylematu, w którym zamknął się Hiob. Bóg, którego odrzuca Sartre, również jest bożkiem, który powinien chwalić tego, kto czyni dobro, i karać za popełnione zło. Gdyby Sartre potrafił dowieść, że bycie dobrym lub złym nie ma żadnego znaczenia - ponieważ, jak twierdzi, dobro i zło są pojęciami wewnętrznie sprzecznymi - tym samym udowodniłby, że ów bóg nie istnieje ${ }^{7}$.

Próba unicestwienia Boga przez francuskiego egzystencjalistę wiąże się z uproszczonym spojrzeniem na Bożą sprawiedliwość. Zarówno Hiob, jak i Sartre nie są w stanie zrozumieć, dlaczego zło atakuje dobrych ludzi, podczas gdy powinni być nagradzani przez Boga za czynienie Jego woli. Hiob wierzy w ukryty sens działania Bożego wbrew oczywistości męki, która go dotyka, natomiast Sartre odrzuca istnienie bożka, czyli istoty niekonsekwentnej w swoim działaniu. Bohater Diabła i Boga Goetz dochodzi do wniosku, że nie ma dobra i zła, nie ma żadnej nagrody ani kary, a więc nie ma Boga. To człowiek sam decyduje o wartościach moralnych, sam określa, co jest dla niego dobre, a co złe. Być ateistą oznacza dla Sartre'a ubóstwienie człowieka. Potwierdza to myśl zawarta w dramacie Muchy:

Ja tylko istnieję; ja sam zdecydowałem o złu; sam wynalazłem dobro; sam oszukiwałem; sam czyniłem cuda, sam dziś oskarżam się i sam siebie mogę rozgrzeszyć - ja człowiek. Jeśli Bóg istnieje, człowiek jest nicością ${ }^{8}$.

Hiob natomiast, dzięki doświadczeniu bólu egzystencji dotkniętej tajemniczą wolą Boga, został u kresu swojego cierpienia obdarzony chwałą poznania majestatu Stwórcy:

On przenika krańce ziemi, bo widzi wszystko, co jest pod niebem; określił potęgę wiatru, ustalit granice wodzie.

Gdy wyznaczał prawo deszczowi, 
a drogę wytyczał piorunom, wtedy ją widział i zmierzył, wtenczas ją zbadał dokładnie.

A do człowieka powiedział:

Bojaźń Boża - zaiste mądrością,

roztropnością zła unikanie (Hi 28, 24-28).

Słowa te objawiają absolutne i nieosiaggalne dla człowieka wymiary Boskiej Wszechmocy i Wszechwiedzy. Człowiek nie jest w stanie ogarnąć swym rozumem tajemnic związanych ze stworzeniem wszechświata. Nie ma dostępu do Boskiej Mądrości. Jedyną rzeczą, którą powinien czynić, jest uznać Moc i Świętość Boga oraz pełnić Jego wolę.

\subsection{Ból opuszczenia przez Boga na podstawie Psalmu 22 i męki Jezusa Chrystusa}

Psalm zapisany przez Dawida jako wielka lamentacja człowieka cierpiącego i opuszczonego przez samego Boga jednoznacznie odnosi się do mroku duszy Jezusa Chrystusa konającego na krzyżu. Recytował go On przed śmiercią, zwracając się, jak udręczony Hiob, do niezrozumiałego Boga, oddalonego od Sługi Jahwe, jedynego Syna, o nieskończoność milczenia.

Boże mój, Boże mój, czemuś mnie opuścił...?

Czemuś tak daleki od wybawienia mego,

od słów krzyku mojego?

Boże mój, Boże mój, czemuś mnie opuścił?

Daleko od mego Wybawcy słowa mego jęku (Ps 22, 1-3).

Tego rodzaju słowa padają z ludzkich ust dość często. Są to słowa Hioba, słowa króla Dawida i nasze, a nade wszystko słowa Chrystusa, który wypowiada je w imieniu wszystkich skazanych na oddalenie od Boga przez grzech. W nich ludzie znajdują swoisty pomost pomiędzy swoją nędzą a doskonałością Pana. Jezus poprzez swoją mękę przeprowadza ludzkość z gehenny potępienia ku światłu zbawienia. Papież Benedykt XVI w jednej ze swoich katechez środowych mówi:

Jak wiadomo, początkowe wołanie z Psalmu: „Boże mój, Boże mój, czemuś mnie opuścił?", przytoczone jest w Ewangeliach Mateusza i Marka jako okrzyk wydany przez Jezusa umierającego na krzyżu (por. Mt 27, 46; Mk 15, 34). Wyraża ono cały smutek Mesjasza, Syna Bożego, który stoi w obliczu dramatu śmierci, rzeczywistości całkowicie wrogiej Panu życia. Opuszczony przez prawie wszystkich swoich bliskich, zdradzony przez uczniów, którzy się Go wyparli, otoczony przez osoby, które Mu złorzeczą, Jezus dźwiga przytłaczający ciężar misji, która 
wiedzie przez upokorzenie i unicestwienie. Dlatego woła do Ojca, a Jego cierpienie wyrażają bolesne słowa Psalmu. Nie jest to jednak okrzyk rozpaczy, podobnie jak nie było nim wołanie Psalmisty, którego błaganie wyraża różne fazy udręki, ale kończy je wizja chwały, wyraz ufności w Boże zwycięstwo. W tradycji żydowskiej cytowanie początku Psalmu oznaczało nawiązanie do całego utworu, toteż rozdzierająca modlitwa Jezusa, choć pozostaje wyrazem niewymownego cierpienia, wskazuje na pewność chwały. „Czyż Mesjasz nie miał tego cierpieć, aby wejść do swej chwały?” - powie Zmartwychwstały do uczniów z Emaus (Łk 24, 26). W swojej męce - posłuszny Ojcu - Pan Jezus przechodzi przez opuszczenie i śmierć i osiąga życie, by dać je wszystkim wierzącym?

Odpowiedzią na niezrozumiałe cierpienia wszystkich Hiobów świata jest ukrzyżowanie - otwierające ludzkości wszystkich czasów i miejsc wyjście z mroków, które były złudzeniem nieobecności Boga w doświadczeniu ludzkiego bólu.

W osobie Jezusa umierającego w straszliwych katuszach cierpi i umiera sam Bóg, który solidaryzuje się ze wszystkimi doznającymi udręki życia.

Niezwykle przejmującym świadectwem o cierpieniu Boga są słowa rabina Kalorymousa Szapiro z Piaseczna, zapisane w getcie warszawskim 14 lutego 1942 roku w dziele Esz Kodesz („Święty Ogień”):

Dręczony cierpieniem człowiek odczuwa własną samotność. Odczuwa tylko własne cierpienie (...). Ale Bóg odczuwa cierpienia wszystkich swoich stworzeń. (...) Mówi nam nasza święta tradycja, że Bóg cierpi więcej niż jakikolwiek człowiek. Ponieważ Bóg jest nieskończony, Jego ból, spowodowany cierpieniem Jego stworzeń, jest nieskończony. Żaden poszczególny człowiek nie może znieść ani pojąć bólu Boga. (...) Gdyby stworzenie Boże usłyszało dźwięk Bożego płaczu, to cały świat by się rozpadł ${ }^{10}$.

Dalszym ciągiem doświadczenia opuszczenia Jezusa na krzyżu była Jego śmierć i zstąpienie do otchłani. Pisze o tym Joseph Ratzinger:

Wielka Sobota (...) to dzień „śmierci Boga”, dzień, który wyraża niesłychane doświadczenie naszych czasów, przyjmując, że Bóg po prostu jest nieobecny, że kryje Go grób, że już się nie obudzi, nie przemówi, a nawet nie będzie Mu się można sprzeciwiać, tak że po prostu można Go pominąć. „Bóg umarł i myśmy Bo zabili”. Te słowa Nietzschego należą językowo do tradycji chrześcijańskiego

9 Katecheza Benedykta XVI z 14 września 2011, https://www.oaza.pl/cdm/strefa-modlitwy/katechezy-benedykta-xvi-o-modlitwie/15-psalm-22-katecheza-z-14-wrzesnia-2011 (dostęp: 12 listopada 2019).

10 B.Z. SHERwIn, Duchowe dziedzictwo Żydów polskich, Warszawa 1995, s. 100-101. 
nabożeństwa Męki Pańskiej; wyrażają one treść Wielkiej Soboty, że „zstąił do piekieł"11.

Dotychczasowe refleksje przygotowały nas do spojrzenia na szczególne doświadczenie mroków wiary, jakie stało się udziałem św. Teresy od Dzieciątka Jezus i Najświętszego Oblicza, karmelitanki bosej z Lisieux, żyjącej w latach 1873-1897.

\section{UFNOŚĆ DZIECKA NA DRODZE DUCHOWEJ UDRĘKI}

\subsection{Spojrzenie na doświadczenie „ukrzyżowania” Teresy od Dzieciątka Jezus}

Nieprzypadkowo określamy mianem ukrzyżowania to, czego doświadczyła Teresa z Lisieux kilkanaście miesięcy przed swoją śmiercią. Jej agonia została rozciąnięta na długie dni i noce, podczas k tórych słowa Hioba skarżącego się na nieuzasadnione cierpienie oraz wołanie Psalmisty i Jezusa - „Boże mój, Boże mój, czemuś mnie opuścił?" - stały się udziałem młodej karmelitanki z Normandii. Cierpi ona na poważną, nieuleczalną wówczas chorobę, która na pewno zakończy się śmiercią. Udręka fizyczna jest tak wielka, że gnębią ją myśli samobójcze. Wiara jest jednak dla niej czymś fundamentalnym i to ona trzyma ją przy życiu. Swiadczą o tym słowa wypowiedziane do jednej z sióstr, która zwróciła uwagę na ogrom jej cierpienia: „Tak!!! Cóż to za łaska mieć wiarę! Gdybym nie miała wiary, bez wahania zadałabym sobie śmierć" ${ }^{2}$.

Na kilka tygodni przed śmiercią, jak zapisała matka Agnieszka,

Prosiła, aby nie stawiać obok niej trujących lekarstw, przeznaczonych do zewnętrznego użytku, i radziła, aby takich lekarstw nigdy nie zostawiać przy chorych, znoszących podobne do niej tortury, za względu na to, że chorzy mogą zatracić rozum i nie wiedząc, co czynią, zadać sobie śmieréc ${ }^{13}$.

Czytając te słowa, możemy w niewielkim stopniu pojąc ogrom jej przedagonalnej udręki. Mała bohaterka $z$ Lisieux jawi się nam jako ktoś, kto solidaryzuje się w swoim bólu z tymi, co doznają rozpaczy i myśli samobójczych.

Gdybyś tylko wiedziała, jak straszne myśli mnie prześladują. Módl się za mnie mocno, abym nie słuchała Diabła, który chce przekonać mnie o tak wielu kłamstwach. To właśnie rozumowanie najgorszych materialistów narzuca mi się ${ }^{14}$.

J. RATzinger, Wprowadzenie w chrześcijaństwo, Kraków 2018, s. 309.

AgnieszKa od JeZusa, Źótty zeszyt, Warszawa 1998, s. 183.

Tamże, s.9.

14 G. Gaucher, Agonia Teresy, Poznań 2014, s. 151. 
W czasie tej udręki św. Teresa nigdy nie wahała się w swojej wierze i całkowicie ofiarowała wszystko, ,aby otrzymać światło wiary dla biednych niewierzących, dla wszystkich, którzy izolują się od wierzeń Kościoła”. Papież Benedykt XVI powiedział później o jej heroicznej wierności w tych zmaganiach:

Z Maryją, obok Krzyża Jezusa, Teresa doświadczyła wtedy najbardziej heroicznej wiary, jako światło w ciemności, która okupowała jej duszę. Karmelitanka wiedziała, że przeżywa tę wielką próbę dla zbawienia wszystkich ateistów wspótczesnego świata, których nazywała braćmi ${ }^{15}$.

Pielęgniarka, która była przy św. Teresie podczas ostatnich dni jej życia, usłyszała od niej wyznanie: „O moja Matko, bardzo łatwo jest pisać piękne rzeczy na temat cierpienia, ale pisanie jest niczym, niczym! Trzeba w tym być, żeby wiedzieć" ${ }^{16}$.

\subsection{Największy ból duszy św. Teresy z Lisieux}

Ból ciała wyniszczonego chorobą był jedynie zewnętrzną oznaką cierpienia duchowego Małej Tereski. Jako karmelitanka wiedziała, czym jest noc ducha, jednak nie przypuszczała, że może się ona objawić w tak głęboki i straszliwy sposób. Oddajmy głos samej Świętej. Na kartach Dziejów duszy mówi:

Cieszyłam się wówczas wiarą tak żywą, tak jasną, że myśl o Niebie napełniała mnie szczęściem; nie mogłam uwierzyć, że istnieją bezbożnicy nie mający wiary. Sądziłam, że jeśli zaprzeczają oni istnieniu Nieba, tego pięknego Nieba, gdzie Sam Bóg chciałby się stać ich wieczną nagrodą, czynią to wbrew swemu wewnętrznemu przekonaniu. $\mathrm{W}$ radosnych dniach okresu paschalnego Jezus dał mi odczuć, że istotnie są dusze pozbawione wiary, które przez nadużywanie łask utraciły ten cenny skarb, źródło jedynej radości czystej i prawdziwej. Pozwolił On, aby dusze moją spowiły najgęstsze ciemności, że myśl o Niebie, tak dla mnie słodka, stała się przedmiotem walki i udręki... Doświadczenie to nie trwało kilka dni czy kilka tygodni, wygląda na to, że będzie ono trwać aż do godziny wyznaczonej przez Dobrego Boga... godzina ta jeszcze nie nadeszła... (...)

Twoje dziecko, o Panie, zrozumiało jednak boskie światło, więc przeprasza Cię za swych braci, godzi się pożywać chleb boleści tak długo, jak Tobie się będzie podobało, i wcale nie ma ochoty wstać od tego stołu zastawionego goryczą,

15 Nie taka mała droga Teresy z Lisieux. 5 mało znanych faktów z życia świętej, https: //www.pch24. $\mathrm{pl} /$ nie-taka-mala-droga--teresy-z-lisieux--5-malo-znanych-faktow-z-zycia-swietej-pch,54872, i.html? utm_source $=$ facebook\&utm_medium $=$ social\&utm_campaign $=$ post\&utm_term $=$ pch (dostęp: 12 listopada 2019).

16 G. Gaucher, Sw. Teresa z Lisieux. Biografia, Poznań 2014, s. 692. 
przy którym pożywiają się biedni grzesznicy, zanim nadejdzie dzień przez Ciebie wyznaczony... Ale czyż nie może wołać w imieniu swoim i swoich braci: Zmiłuj się nad nami, Panie, bo jesteśmy biedni grzesznicy! O Panie! dozwól nam odejšć usprawiedliwionymi... Niech ci wszyscy, którzy nie byli dotąd oświeceni jasnymi promieniami Wiary, zobaczą w końcu jej światło... O Jezu, jeśli trzeba, by dusza miłująca Ciebie oczyściła stół przez nich skalany, pragnę gorąco pożywać ten chleb ciężkich doświadczeń aż do chwili, w której spodoba Ci się wprowadzić mnie do Twego promiennego królestwa. O jedną tylko łaskę proszę, abym Cię nigdy nie obraziła... ${ }^{17}$

Teresa z Liesieux przeżywa stan wielkiej ciemności duszy, nie czuje żadnej radości i satysfakcji z wiary, wręcz odwrotnie: wydaje jej się, że pogrążona została na wieki w pustce opuszczenia przez Boga. Jest jak Hiob. Wie, że cierpi nie z powodu swoich grzechów, lecz źródłem jej bólu jest Boże postanowienie. To Bóg chce, by doznała katuszy tych, którzy w Niego nie wierzą, i w ten sposób wniosła w ich doświadczenie nadzieję. Teresa pragnie być przedstawicielką ateistów przed Majestatem Najwyższego. Jest jak Jezus cierpiący za grzeszników i otwierający im drogę do zbawienia. Pustka współczesnego świata, pustka, w której nie można już dostrzec śladów Boga, w doświadczeniu Teresy zostaje wypełniona światłem wiary w ciemności, wiary wbrew pokusie nihilizmu i rozpaczy. Mała święta z Lisieux staje się ambasadorką czasów współczesnych, staje bowiem po stronie wszystkich dotkniętych chorobą najcięższą z możliwych, a mianowicie brakiem więzi z Bogiem. Ona ich nie potępia, ale ból ich duszy podnosi ku milczącemu Najwyższemu. Jej cierpienie staje się pomostem pomiędzy bezbożnością a bliskością z Tym, który JEST. Doświadczenie Hioba i Jezusa, doświadczenie opuszczenia przez Boga i Jego milczenia jest czymś, co charakteryzuje stan naszego współczesnego ducha. Teresa swoim bólem, złączonym z Krzyżem, otwiera nam drogę do światła wiary. Staje się jej nauczycielką dla tych, którzy nie potrafią poradzić sobie z pustką otaczających nas ciemności.

17 Teresa od DzieciąTKa Jezus, Dzieje duszy, Kraków 2016, s. 255-256. 


\section{WYBRANA BIBLIOGRAFIA}

Pismo Święte Starego i Nowego Testamentu, Poznań ${ }^{3} 1980$.

AgnieszKa od Jezusa, Żótty zeszyt, Warszawa 1998.

BeCKeTt S., Utwory wybrane, Warszawa 2017.

Gaucher G., Agonia Teresy, Poznań 2014.

Gaucher G., Św. Teresa od Dzieciątka Jezus. Biografia, Poznań 2014.

Jan Pawee II, Salvifici doloris - O chrzescijańskim sensie ludzkiego cierpienia, Rzym 1984.

Louf A., Żyć łaską, Kraków 2004.

Ratzinger J., Wprowadzenie w chrześcijaństwo, Kraków 2018.

Różewicz T., Wybór poezji, Wrocław 2019.

SARTre J.-P., Diabet i Bóg, „Dialog” 9 (1959).

SARTRE J.-P., Dramaty, Warszawa 1956.

Sherwin B.Z., Duchowe dziedzictwo Żydów polskich, Warszawa 1995.

Stinissen W., Noc jest mi świattem, Kraków 1993.

Teresa od DzieciątKa Jezus, Dzieje duszy, Kraków 2016.

\section{ABSTRACT}

BartŁomiej Józef KuCharski, OCD

The Darkness of Faith in the Contemporary World.

The Believer's Answers on the Basis of the Book of Job and Ps 22

as well as the Experiences of St Thérèse from Lisieux

The present day is marked by wounds inflicted by two totalitarianisms: Nazism and communism. The fruit of their impact is the ever-growing sense of God's absence in the spiritual experience of contemporary times. This paper refers to the testimonies of two artists: Beckett and Różewicz, to show the mood of the time of God's death. John Paul II called this experience "a collective dark night enveloping the world." Then it uses biblical testimonies to reveal that the issue of God who is absent or silent appears in the Book of Job or in Psalm 22 as well as in the descriptions of Jesus' passion. These reflections lead to present the contemporary context of these biblical passages. Job's torment is compared to the experiences described in the dramas of J.P. Sartre. In turn, Ps 22 and the Passion of Jesus carry with them the interpretation of the experience of the death of God that the contemporary world is experiencing. The culmination of all the considerations is to show the anguish of the night of faith of Thérèse of Lisieux. At the end of her life she lost her joy flowing from faith. She thought that there was no heaven and that after death a darkness of 
nothingness awaited her. Her experience was connected with serious physical sufferings. Therèse's agony seems to be a response to the dilemmas of contemporary times. Through her pain the Saint of Lisieux carries sufferings of atheists and through her intercession she pleads the grace of faith for them. Thérèse is a gift for the times when God seems to be absent and silent. Her faith, despite her experiences of emptiness and nothingness, saves the lost inhabitants of our times.

Keywords: suffering, loneliness, faith, atheism, salvation

Słowa klucze: cierpienie, opuszczenie, wiara, ateizm, zbawienie 